\title{
KEMAMPUAN MENGGUNAKAN METODE DEBAT AKTIF SEBAGAI KETERAMPILAN BERBICARA PADA SISWA KELAS VIII SMP NEGERI 30 SURABAYA
}

\author{
Eleonora Yosephina Wagu, Riko \\ Universitas Dr. Soetomo \\ Jalan Semolowaru 84 Surabaya \\ Email: eleonora.yosephina@gmail.com
}

\begin{abstract}
Abstrak
Metode debat aktif ini merupakan salah satu metode yang diciptakan oleh Melvin L. Silberman dalam pembelajaran aktif (active learning). Metode ini digunakan untuk menstimulasi diskusi kelas. Melalui metode ini setiap siswa didorong untuk mengemukakan pendapatnya melalui suatu perdebatan antar kelompok diskusi yang disatukan dalam sebuah diskusi kelas. Keterampilan berbicara merupakan kecakapan yang memerlukan koordinasi otot dan syaraf dalam mengucapkan bunyi-bunyi yang bermakna, penyampaian gagasan, usul, serta pemikiran pada orang lain. Penelitian ini dilaksanakan dengan tujuan untuk mendeskripsikan kemampuan siswa menggunakan metode debat aktif sebagai keterampilan berbicara.Dalam penelitian inimenggunakan rancangan penelitian deskripsi kualitatif.Instrumen yang digunakan dalam penelitian ini berupa instrumen tes berupa keterampilan berbicara menggunakan metode debat aktif dan instrument nontes berupa observasi dan wawancara.Pengumpulan data berupa Teknik tes,teknik observasi dan wawancara.Analisis data dimulai dari tahap reduksi data,tahap penyajian data,dan tahap verifikasi data. Berdasarkan hasil analisis data, dapat diperoleh hasil penelitian sebagai berikut. Pertama, masalah keterampilan berbicara dari aspek kebahasaan dan non kebahasaan menggunakan metode debat aktif. Kedua, masalah keaktifan siswa belajar menggunakan metode debat aktif. Ketiga, masalah tanggapan dan respon siswa tentang metode debat aktif.
\end{abstract}

Keyword : debat, aktif, berbicara.

\section{PENDAHULUAN}

Pendidikan adalah suatu proses dalam langkah mempengaruhi peserta didik supaya mampu menyesuaikan diri sebaik mungkin dengan lingkungannya dan dengan demikian akan menimbulkan perubahan dalam dirinya yang memungkinkannya untuk berfungsi secara kuat, aktif dan tanggap dalam kehidupan bermasyarakat. Pendidikan merupakan kata kunci untuk memajukan dan meningkatkan kecerdasan bangsa.Pengajaran adalah perpaduan dari dua aktivitas, yaitu aktivitas mengajar dan aktivitas belajar.Belajar aktif ditafsirkan sebagai usaha membangun pengetahuan dalam diri siswa.

Dalam proses pembelajaran terjadi perubahan dan peningkatan mutu kemampuan, pengetahuan dan keterampilan siswa baik dalam ranah kognitif, afektif dan psikomotorik. Tenaga kependidikan merupakan suatu komponen yang penting dalam penyelenggaraan pendidikan yang bertugas menyelenggarakan kegiatan belajar, melatih, meneliti, mengembangkan, mengelola dan memberikan pelayanan teknis dalam bidang pendidikan (Hamalik, 2008: 9).
Peserta didik merupakan suatu komponen masukan dalam sistem pendidikan yang selanjutnya diproses dalam proses pendidikan sehingga menjadi manusia yang berkualitas sesuai dengan tujuan pendidikan nasional sebagai suatu komponen pendidikan, peserta didik dapat ditinjau dari berbagai pendekatan antara lain pendekatan sosial, pendekatan psikologis dan pendekatan edukatif. Bagi peserta didik, bahasa Indonesia merupakan bahasa resmi dan bahasa pengantar di sekolah.Upaya peningkatan kualitas pendidikan tidak dapat berhasil dengan maksimal tanpa didukung oleh adanya peningkatan kualitas pembelajaran.

Sekolah adalah sistem interaksi sosial suatu organisasi keseluruhan terdiri atas interaksi pribadi terkait bersama dalam suatu hubunganan organik (Wayne dalam Atmodiwiro, 2000).Sedangkan berdasarkan undang-undang no. 2 tahun 1989 sekolah adalah suatu pendidikan yang berjenjang dan berkesinambungan untuk menyelenggarakan kegiatan belajar mengajar. Menurut Daryanto (1997) ,sekolah adalah bangunan atau lembaga untuk belajar serta tempat menerima dan memberi pelajaran Jadi, 
sekolah sebagai suatu sistem sosial dibatasi oleh sekumpulan elemen kegiatan yang berinteraksi dan membentuk suatu kesatuan sosial sekolah yangdemikian bersifat aktif kreatif yang artinya sekolah dapat menghasilkan suatu yang bermanfaat bagi masyarakat dalam hal ini adalah orang-orang yang terdidik.

Kegiatan berbicara tidak terlepas dari kehidupan sehari-hari.Dalam setiap kesempatan, wanita, pria, anak-anak hingga orang dewasa selalu melakukan kegiatan berbicara. Hal yang dibicarakan pun bervariasi, antara lain mengenai materi pelajaran di sekolah, pengetahuan umum, serta isu atau gosip yang berkembang di masyarakat.

Paul T. Rankin (Maulana, 2000) mengadakan survei mengenai penggunaan waktu untuk keterampilan berbahasa terhadap 68 orang dari berbagai pekerjaan dan jabatan selama dua bulan.Hasil survei menerangkan bahwa mereka menggunakan waktu berkomunikasi menyimak $45 \%$, berbicara $30 \%$, membaca $16 \%$, dan menulis 9\%.Uraian di atas menunjukkan bahwa kegiatan berbicara memang banyak dilakukan orang dalam kehidupan bermasyarakat.Menurut Haryadi dan Zamzani (1996), berbicara merupakan tuntutan kebutuhan manusia sebagai makhluk sosial (Homo hominie socius) agar mereka dapat berkomunikasi dengan sesamanya.

Menurut Arsjad dan Mukti (1991) dari kenyataan berbahasa, seseorang lebih banyak berkomunikasi secara lisan dibandingkan dengan cara lain. Dalam kehidupan sehari-hari lebih dari separuh waktu digunakan untuk berbicara dan mendengarkan. Berbicara merupakan sebuah proses komunikasi dengan orang lain. Melalui berbicara, seseorang dapat menyampaikan keinginan dan kebutuhannya pada orang lain.Pada saat berbicara,pembicara harus mengatakan atau menyampaikan pesannya denganjelas agar oramh lain paham.

Menurut Zahroh dan Sulistyorini (Suwadi, 2010) untuk menghasilkan tuturan yang baik, pembicara atau pewicara dituntut mengikuti aturan berbicara, di samping menguasai komponen-komponen yang terlibat dalam kegiatan berbicara atau wicara. Komponenkomponen tersebut, antara lain: 1) penguasaan aspek kebahasaan, dan 2) aspek non kebahasaan. Aspek-aspek tersebut meliputi lafal, tata bahasa, kosakata, kefasihan, dan pemahaman.Dengan demikian, untuk dapat berbicara secara baik diperlukan keterampilan yang kompleks.
Orang yang berani berbicara lebih dikenal oleh orang lain dan sering terlibat dalam acara-acara besar dibandingkan orang-orang yang menutup diri dan tidak berani berbicara di depan publik. Sebagai contoh, dalam sebuah acara yang dipilih menjadi master of ceremony adalah orang-orang yang memiliki kepercayaan diri tinggi, tidak canggung berbicara, serta berani tampil di depan publik. Sementara orang yang memiliki banyak pengetahuan, namun tidak berani tampil tidak pernah terlibat pada saat membawakan acara. Menurut Rogers (2004), ketidakmampuan berbicara di depan publik bukan saja memalukan, tetapi juga bisa menghambat promosi jabatan pekerjaan dan menghancurkan kesempatan untuk menunjukkan keahlian.

Menurut Stewart dan Kenner Zimmer (dalam Haryadi dan Zamzani), kebutuhan komunikasi yang efektif dianggap sebagai suatu yang esensial untuk mencapai keberhasilan setiap individu, baik aktivitas individu maupun kelompok. Semakin banyak komunikasi maka akan semakin mudah mencapai tujuan. Untuk itu keterampilan berbicara perlu diajarkan sejak dini karena keterampilan ini sangat penting dan berguna dalam aktivitas sehari-hari. Menurut Tarigan (1983:1), semakin terampil seseorang berbahasa, semakin cerah dan jelas pula jalan pikirannya. Keterampilan hanya dapat diperoleh dan dikuasai dengan jalan praktik dan banyak latihan.Melatih keterampilan berbahasa berarti pula melatih keterampilan berpikir.

Keterampilan berbicara selalu berkaitan dengan tiga keterampilan berbahasa yang lain, yaitu keterampilan menyimak, membaca, dan menulis. Seluruh keterampilan ini sebaiknya diajarkan sejak anak berusia dini. Menurut Tarigan (2008) dalam memperoleh keterampilan berbahasa, biasanya kita melalui suatu hubungan urutan yang teratur: 1) mula-mula pada masa kecil kita belajar menyimak bahasa, kemudian 2) berbicara, sesudah itu kita belajar 3) membaca, dan 4) menulis.

Menurut Tarigan (1983) menyimak dan berbicara dipelajari oleh anak sebelum memasuki sekolah.Keempat keterampilan tersebut pada dasarnya merupakan suatu kesatuan, merupakan catur tunggal.Anak yang baru saja lahir belum bisa melakukan banyak hal, namun anak memiliki kemampuan menyimak bunyi-bunyi yang ada di sekitarnya. Kemampuan menyimak ini menjadi modal utama untuk mengembangkan keterampilan selanjutnya, yaitu keterampilan 
berbicara. Pada usia satu tahun, anak bisa mengucapkan beberapa huruf dari hasil simakan selama berbulan-bulan.

Demikian juga pengembangan keterampilan berbicara yang terdiri dari berbagai macam bentuk kegiatan berbicara mulai dari yang sederhana hingga kegiatan berbicara paling sulit. Bentuk kegiatan berbicara antara lain menjawab pertanyaan, bercerita, deklamasi, berdiskusi, bermain peran, berpidato, dan sebagainya. Melalui kegiatan berbicara ini diharapkan siswa akan terampil berbicara, namun kenyataannya tidak demikian karena masih banyak terjadi masalah dalam kegiatan berbicara.

Menurut Rogers (2004), ketika seseorang menjadi pembicara di depan publik atau masyarakat, pembicara hanyalah seorang diri, sedangkan para pendengar menjadi sekelompok pendengar yang mendegarkan dan mengamati pembicara. Posisi ini dapat menyebabkan pembicara menjadi gugup, cemas, dan kehilangan konsentrasi yang akan mengakibatkan pembicara menjadi tidak mampu berbicara.

Menurut Wiyanto dan Astuti (2004), berbicara di depan umum cukup mudah, namun juga sulit. Dikatakan mudah karena setiap hari semua orang berbicara, dikatakan sulit karena tidak semua orang berani berbicara dan melakukan pembicaraan di depan umum. Ada hambatan yang mengganggu kelancaran berbicara di muka umum, terutama bagi pembicara pemula. Bagi yang belum berpengalaman, berbicara di depan umum sangat menakutkan karena adanya rasa takut dan mungkin juga malu yang menyebabkan rasa resah dan gelisah.

Seseorang yang tidak mampu berbicara didepan publik seringkali mengalami gejalagejala tertekan yang terdiri dari gejala fisik, mental, dan proses mental. Menurut Roger (2004) gejala fisik antara lain: 1) detak jantung yang semakin cepat, 2) suara yang bergetar yang seringkali disertai mengejangnya otot tenggorokan atau terkumpulnya lendir di tenggorokan, dan 3) hiperventilasi termasuk kesulitan untuk bernapas. Gejala yang termasuk proses mental antara lain: 1) mengulang kata, kalimat, atau pesan, 2) hilang ingatan, termasuk ketidakmampuan pembicara untuk mengingat fakta atau angka secara tepat, dan melupakan halhal yang sangat penting, dan 3) tersumbatnya pikiran yang membuat pembicara tidak tahu apa yang harus diucapkan selanjutnya. Sementara yang termasuk gejala fisik dan mental yaitu rasa takut, rasa tidak mampu, rasa hilang kendali, rasa tidak berdaya, rasa malu, dan panik.

Berbicara sebagai salah satu dari empat keterampilan berbahasa memiliki peran yang sangat penting dalam berkomunikasi.Pembelajaran bahasa Indonesia diarahkan untuk meningkatkan siswa agar mampu berkomunikasi, baik secara lisan maupun tertulis. Selain untuk meningkatkan siswa agar mampu berkomunikasi, pembelajaran bahasa Indonesia bertujuan agar siswa memiliki sikap positif yaitu mau menggunakan bahasa Indonesia dengan baik dan benar dalam berkomunikasi.

Berdasarkan hasil observasi dan wawancara yang pernah dilakukan bahwa nilai yang dicapai siswa kelas VIIIA yang berjumlah 36 siswa pada materi Berita dengan mempresentasikan hasil pekerjaan didepan kelas masih sangat rendah.Dari 36 siswa yang berada dikelas VIIIA hanya 9 siswa yang dapat mempresentasikan pekerjaan di depan kelas sesuai dengan ketenntuan yang ada,dan 27 siswa lainnya masuk dalam kategori sedang hingga rendah sekali.Metode yang digunakan dalam pembelajaran berbahasa, khusunya berbicara, kurang bervariasi. Hal ini menyebabkan siswa jenuh dan kurang berpartisipasi dalam kegiatan pembelajaran Bukan hanya itu dalam pelajaranpun siswa lebih banyak diam,hal ini yang menyebabkan kondisi dalam kelas menjadi mati dan siswa akan semakin tidak mampu untuk berbicara sehingga peneliti ingin mengubah kondisi pembelajaran yang pasif menjadi kondisi pembelajaran yang aktif dan menarik salah satunya penerapan metode debat aktif.

Salah satu upaya untuk meningkatkan keterampilan berbicara adalah dengan menggunakan metode debat aktif. Menurut Tarigan (1983) debat merupakan latihan atau praktik persengketaan atau kontoversi.

Menurut Widana, (I Ayu Ketut Sriwahyuni, dkk, 2013) debat pada hakekatnya merupakan suatu bentuk gaya komunikasi yang menitikberatkan pada kemampuan mengkomunikasikan suatu permasalahan dengan mempertimbangkan aturan-aturan tertentu sehingga permasalahan tersebut bisa terpecahkan dengan alasan-alasan yang jelas dan masuk akal. Menurut Wyatt dan Looper (Marleny Leasa dan Yulian Ernawati,2013: 10), bahwa succesfull learning comes from doing. Menurut survei, belajar yang paling efektif adalah dari apa yang dikatakan dan dilakukan. Keberhasilan belajar pada materi yang dikatakan dan dilakukan 
mencapai angka 90\%, sedangkan pengalaman belajar dari materi yang dibaca hanya mencapai angka $10 \%$, dari apa yang didengar mencapai $20 \%$, dari apa yang dilihat mencapai $30 \%$, dari apa yang dilihat dan didengar mencapai $50 \%$, dari apa yang dikatakan mencapai $70 \%$, dan dari apa yang dikatakan dan dilakukan mencapai 90\%. Artinya agar kegiatan pembelajaran berhasil siswa harus dapat mengungkapkan gagasannya dan melakukan (mempraktikan) materi pelajaran yang baru saja diterima. Melalui penggunaan metode debat aktif dalam kegiatan pembelajaran di SMPN 30 Surabaya, diharapkan siswa-siswa kelas VIII A menjadi terampil berbicara, dapat berpikir kritis, serta terjadi penerapan berbagai metode pembelajaran yang menyenangkan bagi siswa.

\section{METODE PENELITIAN}

Jenis penelitian ini adalah deskriptif. Penelitian deskriptif yaitu penelitian yang berusaha untuk menuturkan pemecahan masalah yang ada sekarang berdasarkan data-data. Penelitian ini dilaksanakan pada mata pelajaran bahasa Indonesia mengenai keterampilan berbicara menggunakan metode pembelajaran debat aktif. Tempat yang dijadikan objek penelitian adalah SMPN 30 Surabaya. Teknik pengumpulan data yang digunakan dalam penelitian ini adalah tes, observasi, dan wawancara. Teknik analisis data meliputi reduksi, penyajian data, dan penarikan kesimpulan.

\section{HASIL DAN PEMBAHASAN Hasil Penelitian}

Untuk mengawali kegiatan pembelajaran dengan mengucapkan salam dan memeriksa kehadiran siswa. Kegiatan pembelajaran dilanjutkan dengan apersepsi. Guru melakukan apersepsi menggunakan metode ceramah. Selanjutnya, guru menyampaikan kegiatan pembelajaran beserta tujuan pembelajaran pada siswa Kegiatan setelah menyampaikan kegiatan dan tujuan pembelajaran.

Pelaksanaan kegiatan pada guru memberi penjelasan tentang materi keterampilan berbicara,materi debat, menggunakan media TIK berupa presentasi powerpoint dan video pembelajaran yang membantu siswa memahami debat. Setelah memberi penjelasan peneliti di bantu oleh guru membagi siswa kedalam dua kelompok yaitu kelompok Pro dan kontra .Dan guru menjelaskan prosedur debat.Diantara kelompok pro dan kontra dibagi lagi menjadi subkelompok kecil ,kelompok pro terdiri dari tim A,B,C dan kelompok kontra terdiri dari tim D,E,F agar semua siswa bisa aktif dan berdiskusi dengan mudah.Posisi tempat duduk siswa diatur saling berhadapan antara kelompok pro dan kontra agar siswa dapat berdebat dengan leluasa. Pengaturan tempat duduk siswa membuat kelompok A berhadapan dengan kelompok D, kelompok B dengan kelompok E, dan kelompok $\mathrm{C}$ berhadapan dengan kelompok $\mathrm{F}$.

Guru menetukan tema debat yaitu tema debat "Perkembangan Teknologi sekarang ini membuat anak-anak di Indonesia menjadi jarang membaca buku"

1) siswa yang tergabung dalam kelompok mendiskusi manfaat dan kerugian Teknologi sekarang ini dengan topik "Perkembangan Teknologi sekarang ini membuat anakanak Indonesia jarang membaca buku"

2) Guru berkeliling membimbing siswa saat berdiskusi

3) Guru sebagai moderator mempersilakan sisiwa untuk menyampaikan argument pembuka.

4) Argumen pembuka yang pertama disampaikan kelompok E yang menyampaikan "kami tidak setuju dengan adanya perkembangan teknologi khususnya media sosial dimana banyak pelajar yang salah menggunakan media sosial"Kelompok F mengatakan "perkembangan teknologi juga membuat anak-anak Indonesia terlalu asyik menikmati dan hampir tidak pernah membaca buku"

5) Kelompok A menyampaikan "kami setuju perkembangan teknologi membuat anakanak jarang membaca buku,karena di zaman yang semakin maju ini segelanya bisa kita pelajari dengan teknologi yang ada misalnya; dengan laptop, komputer,handphone dan lain sebagainya. Kelompok B menyampaikan "Di Zaman Sekarang ini teknologi dapat membantu anak-anak belajar mandiri". Kelompok C menyatakan "Teknologi juga dapat membuat anak-anak Indonesia menikmati perkembangan zaman dan mereka jugamembaca dengan menggunakan teknologi yang telah ada"

6) Kelompok $F$ segara membahas pendapat kelompok $\mathrm{C}$ secara spontan tidak berdiskusi terlebih dahulukarena saat berdiskusi sudah ada kesepakatan dan kesepaham 
kelompok.Kelompok F membahas "kalau begitu penggunakan aplikasi hiburan seperti game terbaru,aplikasi tik tok, dan aplikasi foto selfi.Apakah aplikasi di zaman modern ini membuat anak-anak bisa belajar?

7) Kelompok $\mathrm{C}$ segera membalas pendapat dari kelompok $\mathrm{F}$ dengan Mengatakan "Tentu pasti ada anak-anak yang mencari siapa pendiri aplikasi itu, apa tujuan aplikasi itu dibuat. Dan ini juga menjadi pelajaran buat anak-anak Indonesia,mungkin dengan menggunakan suatu saat mereka bisa menciptakan aplikasi " Dan kelompok A juga menambahkan dengan menyatakan "Kita hidup di Zaman yang semakin berkembang "Bukan tidak mungkin di Abad ke 23 kita belajar menggunakan laptop dengan aplikasi google bukan buku yang digunakan.Sekarang saja kita ujian nasional menggunakan komputer bukan kertas “

8) Kelompok D spontan menyanggah pendapat dari kelompok A ,namun kelompk D berbicara terbata-bata .Moderator pun menguatkan kelompok D agar lebih berani mengeluarkan pendapat, dan kelompok D mengulanggi pendapatnya dengan menyampaikan “ Menurut kelompok kami materi yang ada di google sumbernya tetaplah dari buku ,anak-anak yang menggunakan aplikasi google adalah anak anak yang maunya serba instan dan yang membaca menggunakan laptop atau $\mathrm{Hp}$ waktu membaca paling cuman sedikit saja selebihnya menggunakan aplikasi lain kaya bermain game dan lain sebagainya "kelompok F setuju dengan pendapat kelompok $\mathrm{D}$ dan menambah pendapat sendiri.

9) Kelompok kelompok lainpun saling menyanggah dan menyampaikan pendapatnya.

10) Moderator memberi semanagat kepada seluruh kelompok dan menggulang pendapat yang telah disampaikan sebagai pancingan untuk kelompok lain.

11) Moderator mempersilakan kelompok menyiapkan argument penutup setelah semua kelompok berdebat.Guru dan siswa membahas kembali tema debat dengn pendapat-pendapat dari masih kelompok .

12) Guru memuji keberanian siswa dalam berbicara dan mendorong siswa agar tetap semangat.
Setelah pembelajaran langsung, peneliti melakukan tes dengan indikator penilaian yang meliputi.

\begin{tabular}{|l|l|l|l|}
\hline No & Aspek yang dinilai & Unsur-unsur & Skor maksimal \\
\hline 1. & Kebahasaan & a.Tekanan & 10 \\
\hline & & b.ucapan & 15 \\
\hline & & c.kosa-kata/diksi & 15 \\
\hline & & d.struktur kalimat & 20 \\
\hline 2. & Non kebahasaan & e.kelancaran & 10 \\
\hline & & f.keberanian & 15 \\
\hline & & g.penguasaan topik & 15 \\
\hline & & Jumlah & 100 \\
\hline
\end{tabular}

Berikut ini hasil nilai dari kelompok yang telah dibentuk.

\begin{tabular}{|l|l|l|l|l|l|l|l|}
\hline $\begin{array}{l}\text { Aspek yang } \\
\text { nilai }\end{array}$ & Unsur-unsur & A & B & C & D & E & F \\
\hline Kebahasaan & a.tekanan & 9 & 8 & 9 & 9 & 6 & 9 \\
\hline & b.ucapan & 12 & 9 & 11 & 10 & 10 & 11 \\
\hline & c.kosa kata & 13 & 11 & 12 & 12 & 9 & 11 \\
\hline & $\begin{array}{l}\text { d.struktur } \\
\text { kalimat }\end{array}$ & 16 & 10 & 13 & 16 & 10 & 10 \\
\hline $\begin{array}{l}\text { Non } \\
\text { kebahasaan }\end{array}$ & e.kelancaran & 8 & 8 & 8 & 10 & 6 & 8 \\
\hline & f.keberanian & 15 & 10 & 12 & 15 & 12 & 15 \\
\hline & $\begin{array}{l}\text { g.penguasaan } \\
\text { topik }\end{array}$ & 15 & 15 & 15 & 15 & 15 & 15 \\
\hline & Jumlah Nilai & 88 & 71 & 80 & 87 & 68 & 76 \\
\hline
\end{tabular}

Selama kegiatan pembelajaran guru bertindak sebagai fasilitator dan motivator yang membantu siswa memberikan informasi, mengevaluasi kegiatan siswa dan membimbing siswa.

Siswa yang aktif bertanya dan berkomentar semakin bertambah ,siswa memperhatikan penjelasan guru dengan baik,situasi kelaspun ikut baik dan kondusif . Setelah siswa memperhatikan contoh kegiatan debat dengan baik .Guru mempersilakan siswa duduk dalam kelompok dan siswa mengikuti arahan guru dengan baik .siswa menyiapkan argumen masing-masing kelompok dan berdiskusi tentang argumen.pada pertemuan kedua siswa semakin aktif dalam berdiskusi kerja sama tim semakin meningkat .Setelah berdiskusi menyiapkan argumen siswa aktif menunjukan pembicara masing -masing kelompok dan siswa juga aktif bertukar pikiran ,siswa yang tidak pernah aktif dalam pembelajaran sudah memulai berbicara dengan baik untuk membantu juru bicara menyampaikan pendapat .Baik itu kelompok pro mau kelompok kontra pada pertemuan ini siswa bisa dikatakan aktif untuk berargumen, bertukar pikiran ,menguasai topik 
dan untuk menanggapi pendapat kelompok lawan.Kerja sama tim pada pertemuan ini baik siswa sangat aktif dalam pembelajaran menggunakan metode debat aktif.

Aspek-aspek keterampilan berbicara yang terdiri dari unsur tekanan, ucapan, pemilihan kosa kata, struktur kalimat, keberanian, kelancaran, dan penguasaan topik dapat dikuasai dengan baik pada pertemuan ini. Siswa dapat memberi tekanan dalam setiap kalimat dengan baik sehingga pendapat siswa mudah dimengerti siswa lain. Pemilihan kosa kata/ diksi sangat baik.Kalimat yang disampaikan tidak mengandung kosa kata bahasa daerah dan sudah sesuai dengan topik pembicaraan.Struktur kalimat pun tersusun dengan baik.Rangkaian kalimat siswa mengikuti pola kalimat yang tepat. Namun, siswa masih perlu diberi banyak latihan dalam kegiatan berbicara agar siswa benar-benar memahami dan dapat menerapkan struktur kalimat yang tepat.

Keberanian dan kelancaran dikuasai dengan sangat baik oleh siswa kelas VIII A SMPN 30 Surabaya. Hampir seluruh siswa dapat menyampaikan pendapat dengan percaya diri dan suara lantang.Siswa berbicara dengan lancar, tidak canggung, dan tidak terbatabata.Penguasaan topik pun sudah baik karena siswa dapat mempertahankan pendapat kelompoknya, menyanggah pendapat kelompok lawan, serta memberikan solusi atas masalah atau topik yang diperdebatkan.

Berdasarkan hasil wawancara yang telah dilakukan peneliti tentang tanggapan siswa berkaitan dengan pembelajaran debat aktif kepada siswa kelas VIII A diperoleh data sebagai berikut:

Dari 36 siswa di kelas VIII A ,34 siswa yang memberikan tanggapan positif dan mengalami kemudahan dalam berbicara dan menuangkan ide menggunakan metode debat aktif dan 2 siswa lainnya masih merasa gugup dalam berbicara.Dan dari 36 siswa semuanya memberikan tanggapan positif tentang pembelajaran debat aktif karena dapat melatih siswa berbicara dan siswa merasa senang dan tertarik belajar menggunakan metode debat aktif yang baru pertama kali digunakan. Siswa kelas VIII A juga memberi tanggapan mengenai perbedaan metode pembelajaran debat dan metode yang sering digunakan,dari 36 siswa semuanya memberikan tanggapan metode debat membuat siswa tidak bosan dan belajar berbicara dan menuangi ide mereka, metode yang sering digunakan diantanya metode ceramah yang membuat siswa bosan dan cendrung tidak mengikuti pelajaran.

\section{Pembahasan}

Penelitian kemampuan menggunakan debat aktif sebagai keterampilan berbicara dilaksanakan pada kelas VIII A SMP Negeri 30 Surabaya.Aspek keterampilan berbicara sudah dikuasai siswa dan siswa juga aktif dalam debat diantara dalam menguasai tema debat, mempertahankan usulan, menanggapi pertanyaan kelompok dan berdiskusi.

Kegiatan pembelajaran berjalan dengan baik. Siswa menjadi lebih siap mengikuti kegiatan pembelajaran menggunakan metode debat aktif. Siswa merasa lebih percaya diri dan tidak canggung lagi dalam menyampaikan pendapatnya.Siswa pun saling membagi tugas pada sesama anggota kelompok agar seluruh anggota kelompok bisa mengungkapkan pendapatnya dan mendebat kelompok lawan.Kesiapan dan keberanian siswa merupakan hasil dari pengalaman belajar dan latihan berbicara.Kegiatan pembelajaran menggunakan metode debat aktif pada pertemuan ini cukup memuaskan. Keterampilan berbicara siswa meningkat, baik dalam proses dan hasilnya. Hampir seluruh siswa mengalami peningkatan.

Menurut Melvin Silberman (2014: 141) sebuah debat aktif bisa menjadi metode berharga untuk meningkatkan pemikiran dan perenungan. Melalui metode debat aktif, siswa berlatih untuk memikirkan sisi positif dan negatif dari suatu permasalahan. Siswa berlatih berpikir rasional sehingga pemikirannya dapat diterima orang lain. Menurut Hurlock (1980: 151) pada akhir masa kanak-kanak, anak menyadari bahwa bentuk komunikasi sosial seperti menangis dan gerak isyarat tidak diterima secara sosial. Oleh karena itu, anak meningkatkan kemampuan berbicaranya agar hal yang dibicarakan dapat dimengerti orang lain serta dapat memahami pembicaraan orang lain. Anak yang dapat berbicara dengan baik akan diterima oleh kelompok sosial.

Keterampilan berbicara pada pertemuan ini terlaksana dengan baik karena ada berbagai faktor antara lain: 1) guru memberikan bimbingan secara maksimal selama kegiatan pembelajaran, 2) motivasi dan penguatan dari guru membuat siswa percaya diri dan tidak takut menyampaikan pendapatnya, 3) siswa belajar dari pengalaman pada pertemuan pertama I, 4) tema debat aktif yang menarik dan tidak 
melampaui daya tangkap siswa, dan 5) siswa sudah memahami proses pelaksanaan debat aktif.

Secara umum, keterampilan berbicara siswa kelas VIII A dikuasai siswa dalam pertemuan ini. Aspek keterampilan berbicara yang terdiri dari: 1) penggunaan tekanan, 2) ucapan, 3) pemilihan kosa kata, 4) struktur kalimat, 5) kelancaran, 6) keberanian, dan 7) penguasaan topik dikuasai siswa secara bertahap. Pada mulanya, siswa dilatih untuk menguasai aspek keberanian.Keberanian merupakan aspek keterampilan berbicara yang paling awal dikuasai.Keberanian memengaruhi aspek-aspek keterampilan yang lainnya. Apabila siswa sudah memiliki keberanian, maka siswa akan mearasa percaya diri dan lancar dalam mengutarakan pendapatnya pada orang lain. Aspek yang dikuasai setelah kelancaran adalah penggunaan tekanan, nada, dan irama yang berhubungan dengan ucapan dan pemilihan kosa kata/diksi.Semakin sering siswa berlatih mengemukakan pendapat dan berdiskusi, siswa dapat menguasai topik pembicaraan dengan baik.

Aspek terakhir yang dikuasai adalah struktur kalimat.Struktur kalimat secara tertulis berbeda dengan struktur kalimat lisan.Pada tulisan, struktur kalimat lebih tertata karena mengikuti pola kalimat yang benar sehingga pembaca mudah memahami isi tulisan tersebut.Namun,struktur kalimat secara lisan seringkali tidak beraturan dan dapat membuat pendengarnya kebingungan memahami maksud pembicara. Oleh karena itu, struktur kalimat dikuasai setelah aspek-aspek keterampilan berbicara yang lain telah dikuasai dan pembicara terus melatih keterampilan berbicaranya.

Penguasaan aspek-aspek keterampilan berbicara oleh siswa kelas VIII A SMP Negeri 30 Surabaya dibuktikan dengan perkembangan penguasaan aspek-apek keterampilan berbicara. Pada pertemuan ini seluruh aspek keterampilan berbicara telah dikuasai oleh siswa kelas VIII A, namun unsur struktur kalimat perlu ditingkatkan lagi.

Selama kegiatan pembelajaran, ada beberapa orang siswa yang sudah berani berbicara di hadapan guru dan siswa lain. Beberapa dari siswa tersebut merupakan anak yang memiliki kepercayaan diri tinggi, namun ada pula siswa yang belajar untuk lebih berani dalam kegiatan pembelajaran debat aktif. Pada kelompok A hanya ada 3 orang siswa yang sudah berani menyampaikan argumennya, kelompok B ada 2 orang, kelompok $\mathrm{C}$ ada 2 orang, kelompok
$\mathrm{D}$ ada 3 orang, kelompok $\mathrm{E}$ ada 2 orang, dan kelompok $F$ ada 2 orang siswa yang berani berpendapat.

Pada aspek non kebahasaan unsur kelancaran, terjadi kemajuan yang cukup baik.Sebagian besar siswa dapat menyampaikan gagasannya dengan tenang lancar, meskipun masih ada yang terbata-bata dalam mengutarakan pendapat dan pemilihan katanya belum tepat.

Pandangan mata saat berbicara tidak diarahkan pada pendengar.Siswa yang sedang menyampaikan pendapat mengarahkan pandangannya pada buku catatan yang dibacanya, akibatnya pendengar merasa tidak diperhatikan dan suasana kelas menjadi ramai karena siswa mengobrol sendiri.

Penguasaan topik dan struktur kalimat masih perlu ditingkatkan karena siswa lebih sering mengulangi penjelasan guru saat apersepsi serta argumen-argumen yang telah disampaikan.Siswa pun masih kesulitan untuk berbicara dengan struktur kalimat yang tepat.Unsur subyek dan predikat dalam kalimat yang disampaikan siswa sering terbalik.

Semua aspek keterampilan berbicara hampir semua dapat di kuasai siswa dikarena keaktifan siswa dalam berdiskusi kelompok dan juga kesungguhan siswa dalam mempelajari metode debat aktif. Dalam penelitian ini keaktifan siswa dapat dilihat dari inisiatif siswa dalam bekerja sama dan kekompakan siswa dalam berdiskusi untuk mencapai tujuan bersama .Baik kelompok pro maupun kelompok kontra ini keduanya terlihat aktif dalam pembelajaran metode debat ini.Semua siswa mengambil bagian dalam kegiatan debat ini. Dalam berdiskusi semua siswa berargumen untuk mencapai pendapat bersama dalam menyerang atau menanggapi kelompok lawan .Hal ini di lakukan siswa pada setiap pertemuan sehingga kegiatan debat berjalan dengan lancar. Akan tetapi perorganisasian siswa dalam bekerja sama masih belum maksimal dimana masih ada siswa yang tidak memperhatikan bagian-bagian dalam bekerja kelompok.

Keaktifan siswa dalam belajar menggunakan metode debat aktif sangat meningkat dibandingan dengan penggunaan metode sebelumnya.Dimana pada metode ini dapat mensitumulas diskusi kelas,siswa yang hari-harinya jarang aktif dalam belajar perlahanlahan mulai aktif dari awal berinisiatif bekerja sama dan berdiskusi serta menyampaikan argumen untuk menanggapi kelompok lawan. 


\section{SIMPULAN}

Berdasarkan hasil penelitian dapat disimpulkan siswa mampu menggunakan metode debat aktif sebagai keterampilan berbicara. Melalui metode ini keberanian dan kepercayaan diri siswa dapat meningkat. Keberanian memengaruhi kelancaran berbicara siswa. Siswa dapat berbicara dengan tenang dan lancar di hadapan guru dan siswa lain. Penggunaan tekanan dan ucapan, pemilihan kata, serta penguasaan topik pun semakin dikuasai siswa seiring kegiatan pembelajaran menggunakan metode debat aktif. Pada akhirnya, siswa dapat berbicara menggunakan struktur kalimat yang benar dengan berlatih dan mengemukakan pendapatan secara terus menerus. Siswa juga menjadi terbiasa untuk berbicara dalam kelas baik saat bertanya kepada guru,berargumen dan mempresentasikan pekerjaan didepan kelasdan proses pembelajaran berjalan dengan baik. Keaktifan siswa kelas VIII A dalam berbicara menggunakan metode debat maupun berdiskusi dalam kelompok pada setiap pertemuan termasuk sangat baik.Dimana selain menguasai aspek kebahasaan maupun non kebahasaan siswa juga aktif dalam menanggapi, menganggah, mengemukaan pendapat dalam debat serta kekompakan siswa dalam menyiapkan argumen.

\section{DAFTAR PUSTAKA}

Arsjad, Maidar G dan Mukti U.S. 1993. Pembinaan Keterampilan Berbicara Bahasa. Indonesia. Jakarta: Erlangga.

Wiyanto, Asul, dan Prima K. Astuti, 2002. Terampil Membawa Acara. Jakarta: PT.Grasindo.

Hamalik, Oemar. 2008. Kurikulum dan Pembelajaran. Jakarta: Bumi Aksara.

Atmodiwirio, Soebagio. 2000. Manajemen Pendidikan Indonesia. Jakarta: Ardadizya Jaya.

Daryanto. 1997. Evaluasi Pendidikan. Jakarta: Rineka Cipta.

Haryadi \& Zamzani. (1996). Peningkatan Keterampilan Berbahasa Indonesia. Yogyakarta: Depdikbud.
Hanapiah, Jenep dan Suwadi. 2010. Peningkatan Keterampilan Berbicara dengan Teknik Bermain Peran bagi Siswa Kelas V SDN

2 Ngali Kecamatan Belo Kabupaten Bima Tahun 2010-2011. J-TEQIP. 1 (1). Hal. 53-6.

I Ayu Ketut Sriwahyuni, Nyoman Dantes, A.A. Istri Ngurah Marhaeni. 2013. Pengaruh Implementasi Metode Debat Terhadap Keterampilan Berbicara Bahasa Inggris Ditinjau Dari Minat Belajar Kelas Xi Ipa Sma Negeri 2 Amlapura. Journal Program Pascasarjana Universitas Pendidikan Ganesha. 4(1).

Maulana, Afqi. 2000. Cara Berdiskusi/MC dan Pidato. Surabaya: Putra Pelajar.

Rogers, Natalie. 2004. Berani Bicara di Depan Publik: Cara Cepat Berpidato. Bandung: Penerbit Nuansa

Sugiyono. 2014. Memahami Penelitian Kualitatif. Bandung: Alfabeta.

Tarigan HG. 1983 . Berbicara. Bandung: Angkasa. 